\title{
Strategi Peningkatan PAD Melalui Intensifikasi Dan Ekstensifikasi Penerimaan Pajak Daerah Dan Retribusi Daerah Di Kabupaten Enrekang
}

\author{
Nursafitra M1, Muh. Nursadik², Muhammad Yunus ${ }^{3}$ \\ 1Departemen Administrasi Publik, Universitas Hasanuddin, Indonesia. E-mail : nursafitra22@yahoo.co.id \\ 2Departemen Administrasi Publik, Universitas Hasanuddin, Indonesia. E-mail : sadik@tau.ac.id \\ 32Departemen Administrasi Publik, Universitas Hasanuddin, Indonesia. E-mail : myunus59@yahoo.com
}

\section{ARTICLE INFO}

Keywords: Strategy, Increased Income, Local Government

Kata kunci : Strategi, Peningkatan Pendapatan Pemerintah Daerah

\section{How to cite:}

Nursafitra M, Muh. Nursadik, Muhammad Yunus. (2019). Strategi peningkatan PAD melalui intensifikasi dan ekstensifikasi penerimaan pajak daerah dan retribusi daerah di Kabupaten Enrekang. 5(1): $37-48$

\section{ABSTRACT}

Strategy for Increasing Regional Original Income Through Intensification and Extensification of Tax Revenue and Regional Retribution in Enrekang District (Supervised by Nursadik and Muhammad Yunus). This study aims to analyze the Strategy for Increasing Regional Original Revenue through intensification and extensification of regional taxes and levies in Enrekang Regency and to analyze the supporting and inhibiting factors of the Regional Original Revenue Strategy through intensification and extensification of regional tax and retribution receipts in the District Enrekang. This study used a qualitative approach with a type of case study research. Determination of informants was done by purposive sampling technique. The technique of collecting data is done by in-depth interviews, observation and document study. Data were then analyzed by data reduction, data presentation, and conclusion drawing. The results show that the Strategy for Increasing Regional Original Income Through Intensification and Extensification of Regional Tax and Retribution in Enrekang District is carried out with an Intensification Program namely Institutional Aspects namely improving institutional aspects / management of local revenue, management aspects namely increasing the number of taxpayers, adjusting management aspects both administratively and operationally, as well as the Personal Aspect, namely improving the quality of human resources or regional revenue management apparatuses. Extensification efforts are carried out by the creation of new sources of income and policies in the field of investment. So it can be concluded that efforts to intensify and extend are one of the ways that can be taken to increase local revenue.

\begin{abstract}
Abstrak
Strategi Peningkatan Pendapatan Asli Daerah (PAD) Melalui Intensifikasi dan Ekstensifikasi Penerimaan Pajak dan Retribusi Daerah di Kabupaten Enrekang (Dibimbing Oleh Nursadik dan Muhammad Yunus). Penelitian ini bertujuan Untuk menganalisis Strategi Peningkatan Pendapatan Asli Daerah (PAD) melalui intensifikasi dan ekstensifikasi pajak dan retribusi daerah di Kabupaten Enrekang dan Untuk menganalisis Faktor pendukung dan penghambat Strategi Peningkatan Pendapatan Asli Daerah (PAD) melalui intensifikasi dan ekstensifikasi penerimaan pajak dan retribusi daerah di Kabupaten Enrekang. Penelitian ini menggunakan pendekatan kualitatif dengan jenis penelitian studi kasus. Penentuan informan dilakukan dengan teknik Purposive Sampling. Teknik pengumpulan data dilakukan dengan wawancara mendalam, observasi dan studi dokumen. Data kemudian dianalisis dengan reduksi data, penyajian data, dan penarikan kesimpulan Hasil penelitian menunjukkan bahwa Strategi Peningkatan Pendapatan Asli Daerah (PAD) Melalui Intensifikasi dan Ekstensifikasi Penerimaan Pajak dan Retribusi Daerah di Kabupaten Enrekang, dilakukan dengan Program Intensifikasi yaitu Aspek
\end{abstract}




\begin{abstract}
Kelembagaan yakni mempebaiki aspek kelembagaan/pengelolaan pendapatan asli daerah, Aspek ketatalaksanaan yakni peningkatan jumlah wajib pajak,menyesuaikan aspek ketatalaksanaan baik administrasi maupun operasional, serta Aspek Personalianya yakni meningkatkan mutu sumberdaya manusia atau aparatur pengelola pendapatan daerah, Upaya Ekstensifikasi dilakukan dengan Penciptaan sumber-sumber pendapatan baru dan kebijakan di bidang investasi. Sehingga dapat disimpulkan bahwa upaya intensifikasi dan ekstensifikasi merupakan salah satu cara yang dapat ditempuh untuk meningkatkan pendapatan asli daerah.
\end{abstract}

Copyright ( 2019 JAKPP. All rights reserved.

\title{
Pendahuluan
}

Pendapatan Daerah adalah hak pemerintah daerah yang diakui sebagai penambah nilai kekayaan bersih. Pendapatan daerah merupakan komponen yang sangat penting dan strategis dalam struktur APBD, mengingat peranannya dalam membiayai anggaran belanja daerah, pemberian pelayanan kepada publik, mengendalikan defisit anggaran dan meningkatkan kapasitas fiskal daerah.

Penerimaan dari Pajak Daerah dimana realisasi pendapatan dari tahun ke tahun selalu mencapai bahkan melebihi target (Sumber : Badan pendapatan Daerah Kabupaten Enrekang (Data diolah) tahun 2017) tetapi Pendapatan Asli daerah Menunjukkan fluktuasi. Memasuki Triwulan Pertama Tahun 2018 Pemerintah Kabupaten Enrekang gagal memenuhi target yang seharusnya. Pada Triwulan pertama Pemkab Enrekang menargetkan dapat memeroleh 25 persen atau Rp 12,7 miliar dari 11 objek pajak yang ada. Namun, realisasi yang diperoleh hingga bulan April 2018 ini baru mencapai Rp 2 miliar. Melesetnya target PAD di triwulan pertama lantaran sejumlah objek pajak seperti SPJ, PBB dan pajak mineral bukan logam yang menjadi tumpuan justru jauh dari target. Pajak mineral bukan logam dan batuan atau tambang galian $C$ misalnya, ditargetkan mampu memperoleh penghasilan sebesar Rp 3 miliar, tetapi realisasinya di triwulan pertama ini hanya sekitar Rp139 juta, padahal 25 persen dari total target selama 2018 (http ://makassar. tribunnews. com /2018/05/11/bapenda-enrekang-gagal capai target-pad-pada-triwulan-pertama-2018). Selain itu, kurangnya kesadaran masyarakat terhadap pajak bisa sangat berdampak pada pembangunan.

Pendapatan Asli daerah Kabupaten Enrekang berdasarkan beberapa penelitian yang pernah dilakukan dan didukung oleh berbagai informasi dari media online mengenai pengelolaan Pendapatan asli daerah Kab. Enrekang yang mengalami Fluktuasi disebabkan karena realisasi yang tidak mencapai targetnya disebabkan karena data yang tidak akurat, sejumlah objek pajak seperti Pajak Bumi dan Bangunan (PBB), pajak penerangan jalan (PPJ) dan pajak mineral bukan logam yang menjadi tumpuan justru jauh dari target, adanya retribusi daerah yang dihilangkan seperti retribusi pengadaan biaya serta retribusi kebun raya, tidak optimalnya pengelolaan objek wisata sehingga tidak memiliki kontribusi yang besar terhadap pendapatan asli daerah di Kab. Enrekang, Pemungutan pajak hotel, restoran serta kontribusi UMKM yang masih minim, Kinerja Badan Pendapatan daerah (Bapenda) Kab. Enrekang yang dinilai belum maksimal, Penanaman jiwa 
entrepreneursip yang masih kurang di kalangan pejabat Bapenda dimana Tujuannya agar dapat lebih kreatif untuk meningkatkan pendapatan seperti bersinergi dengan OPD lainnya dalam mengelolah suatu usaha. Seperti bekerja sama dengan Dispopar atau pengelola objek wisata untuk mendulang retribusi dari potensi kepariwisataan. Selain itu, kurangnya kesadaran masyarakat terhadap pajak misalnya tunggakan pajak kendaraan yang sejak lima tahun terakhir menunjukkan jumlah yang besar, kurangnya pengawasan serta belum tegasnya penerapan sanksi bagi masyarakat yang tidak membayar pajak dan retribusi di Kabupaten Enrekang.

Dalam rangka meningkatkan kemampuan keuangan daerah agar dapat melaksanakan otonomi, pemerintah melakukan berbagai kebijakan perpajakan daerah, diantaranya dengan menetapkan UU No.28 Tahun 2009 Pajak Daerah dan Retribusi Daerah. Pemberian kewenangan dalam pengenaan pajak dan retribusi daerah tersebut, diharapkan dapat lebih mendorong pemerintah daerah terus berupaya untuk mengoptimalkan PAD, khususnya yang berasal dari pajak daerah dan retribusi daerah. Oleh karena itu Pemerintah Daerah Kabupaten Enrekang harus lebih mengoptimalkan potensi sumber-sumber penerimaan daerah yang ada. Baik upaya pengelolaan sumber-sumber penerimaan secara intensif (intensifikasi) maupun kemungkinan perluasaan objek sebagai sumber penerimaan yang baru (ekstensifikasi). Hal ini dapat dilakukan dengan lebih mengoptimalkan potensi sumber-sumber penerimaan yang selama ini telah ada secara lebih efektif dan efisien.

Penelitian ini mencoba menganalisis dan mengidentifikasi strategi peningkatan pendapatan asli daerah di Kab. Enrekang dengan cara intensifikasi dan ekstensifikasi melihat bagaimana strategi yang dilakukan Badan pendapatan daerah (Bapenda) Kabupaten Enrekang untuk kemudian mencari solusi terbaik serta menganalisis apakah strategi yang diterapkan sudah optimal dalam meningkatkan Pendapatan Asli daerah kabupaten Enrekang kedepannya Terkait dengan dengan hal tersebut, maka dipandang sangat urgen untuk mengkaji bagaimana strategi meningkatkan Pendapatan Asli Daerah (PAD) daerah di Kabupaten Enrekang.

\section{Kajian Literatur}

Pendapatan Asli Daerah (PAD) yaitu penerimaan yang diperoleh daerah dari sumber-sumber dalam wilayahnya sendiri yang dipungut berdasarkan perturaran daerah sesuai dengan peraturan perundang-undangan yang berlaku. Pendapatan Asli Daerah (PAD) menurut Undang-undang No 33 Tahun 2004 Tentang Perimbangan Kekuasaan Antara Pusat Dan Pemerintahan Daerah Pasal 6 Ayat (1) PAD bersumber dari :

a) Pajak Daerah;

b) Retribusi daerah;

c) Hasil pengelolaan kekayaan daerah yang di pisahkan; dan

d) Lain-lain PAD yang sah.

Definisi Undang-Undang Nomor 34 Tahun 2000 dan Peraturan Pemerintah Nomor 66 Tahun 2001 bahwa pajak daerah adalah iuran wajib yang dilakukan oleh orang pribadi atau badan kepada daerah tanpa imbalan langsung yang 
seimbang, yang dapat dilaksanakan berdasarkan Peraturan Perundang-undangan yang berlaku, yang digunakan untuk membiayai penyelenggaraan pemerintah daerah dan pembangunan daerah. Berdasarkan Undang-Undang nomor 28 tahun 2009 tentang pajak dan retribusi daerah maka jenis pajak dan retribusi daerah kabupaten atau Kota yaitu :

1 Pajak daerah yaitu Pajak Hotel, pajak restoran, pajak hiburan, pajak reklame, pajak penerangan jalan, pajak mineral bukan logam dan batuan, pajak parkir, pajak air tanah, pajak sarang burung wallet, pajak bumi dan bangunanan serta bea perolehan hak atas tanah dan bangunan.

2 Retribusi daerah meliputi : Retribusi jasa umum, retribusi jasa usaha dan retribusi perizinan tertentu.

Secara umum pajak adalah pungutan dari masyarakat oleh negara (Pemerintah) berdasarkan undang-undang yang bersifat dapat dipaksakan dan terutang oleh wajib membayarnya dengan tidak mendapat prestasi kembali (kontra prestasi/balas jasa) secara langsung, yang hasilnya digunakan untuk membiayai pengeluaran negara dalam penyelenggaraan pemerintahan dan pembangunan. Hal ini memunjukkan bahwa pajak adalah pmbayaran yang wajib yang dikenakan berdasarkan undang-undang yang tidak dapat dihindari bagi yang berkewajiban dan bagi mereka yang tidak mau membayar pajak dapat dilakukan paksaan (Siahaan, 2005:6)

Retribusi daerah adalah pembayaran wajib dari penduduk kepada negara karena adanya jasa tertentu yang diberikan oleh negara bagi penduduknya secara perorangan. Jasa tersebut dapat dikatakan bersifat langsung, yaitu hanya yang membayar retribusi yang menikmati balas jasa dari negara.

Adapun konsep yang digunakan dalam penlitian ini adalah upaya Intensifikasi menurut Kustiawan (dalam Rahmi, 2013: 5) akan mencakup aspek kelembagaan, aspek ketatalaksanaan, dan aspek personalianya, yang pelaksanaannya melalui kegiatan sebagai berikut :

a. Menyesuaikan atau memperbaiki aspek kelembagaan/organisasi pengelolaan pendapatan asli daerah.

b. Memberikan dampak kearah peningkatan pendapatan asli daerah, karena sistem ini dapat mendorong terciptanya :

1. Peningkatan jumlah wajib pajak dan wajib retribusi daerah,

2. Peningkatan cara-cara penetapan pajak dan retribusi,

3. Peningkatan pemungutan pajak dan retribusi dalam jumlah yang benar dan tepat pada waktunya,

4. Peningkatan sistem pembukuan, sehingga memudahkan dalam hal pencarian data tunggakan pajak maupun retribusi yang pada akhirnya dapat mempermudah penagihannya.

c. Memperbaiki atau menyesuaikan aspek ketatalaksanaan, baik administrasi maupun operasional yang meliputi :

1. Penyesuaian atau penyempurnaan administrasi pungutan,

2. Penyesuaian tarif,

3. Penyesuaian sistem tata laksana pungutan 
d. Peningkatan pengawasan dan pengendalian yang meliputi :

1. Pengawasan dan pengendalian yuridis,

2. Pengawasan dan pengendalian teknis,

3. Pengawasan dan pengendalian penata usahaan.

e. Peningkatan sumber daya manusia dalam pengelola Pendapatan asli daerah dengan cara meningkatkan mutu sumber daya manusia atau aparatur pengelola pendapatan daerah dapat dilakukan dengan mengikutsertakan aparatnya dalam kursus keuangan daerah, juga program-program pendidikan dan pelaithan yang berkaitan dengan pengelolaan keuangan daerah.

f. Meningkatkan kegiatan penyuluhan kepada masyarakat untuk menumbuhkan kesadaran masyarakat membayar pajak dan retribusi.

Adapun konsep ekstensifikasi menurut Abubakar (dalam Halim, 2001:147) “Ekstensifikasi pajak dan retribusi daerah merupakan suatu kebijakan yang dilakukan oleh daerah Kota/Kabupaten dalam upaya meningkatkan penerimaan pajak daerah melalui penciptaan sumber-sumber pajak dan retribusi daerah"

Salah satu kebijakan dalam upaya ekstensifikasi sumber penerimaan dari pajak daerah dan retribusi daerah yang sangat rasional dan tidak menyengsarakan masyarakat adalah kebijakan dibidang investasi. Usaha lain yang dapat dilakukan untuk meningkatkan pendapatan asli daerah adalah dengan menarik investor agar bersedia menanam modalnya di daerah, dengan melakukan promosi serta menciptakan iklim yang kondusif dengan usaha (Rozali, 2000: 47).

Adapun penelitian-penelitian yang pernah dilakukan sebelumnya yang terkait dengan penelitian ini adalah : Penelitian yang dilakukan Andi Ulfa Achsyariana. A. Sarjana Universitas Islam Negeri Alauddin Makassar pada tahun 2017 dengan judul skripsi “Kontribusi Wisata Alam Gunung Nona Terhadap Pendapatan Asli Daerah (PAD) Kabupaten Enrekang". Jenis penelitan ini adalah deskriptif kualitatif tetapi menggunakan kerangka fikir pariwisata dan penerimaan pajak dalam perspektif islam. Berdasarkan hasil penelitian mengenai kontribusi wisata alam Gunung Nona terhadap pendapatan asli daerah (PAD) Kabupaten Enrekang dapat ditarik kesimpulan bahwa kontribusi yang diberikan oleh UMKM yang berada di kawasan wisata alam Gunung Nona dalam kurun waktu 5 tahun yakni 2013 sampai dengan 2017 belum maksimal.

Penelitian yang dilakukan Tri Setyaningsih pada Sarjana Universitas Muhammadiyah Yogyakarta, penelitan ini dilakukan pada tahun 2009 dengan judul skripsi “ Strategi Peningkatan Pendapatan Asli Daerah Dalam Rangka Pelaksanaan Otonomi Daerah (Studi Tentang Strategi Peningkatan Penerimaan Sektor Pajak di Kabupaten Sleman)". Jenis penelitian yang digunakan adalah deskriptif kualitataif dengan penelitian hukum sosiologis atau empiris yang mencakup penelitian terhadap identifikasi hukum tidak tertulis, serta proses interaksi sosiologis masyarakat dalam penerapan hukum. Dengan menggunakan sistem Intesifikasi dan sistem ekstensifikasi untuk mengukur strategi peningkatan Pendapatan Asli daerah di Kabupaten Sleman. Adapun Kesimpulan dari Penelitian tersebut adalah Strategi Pemerintah Daerah Kabupaten Sleman dalam meningkatkan Pendapatan Asli 
Daerah dilakukan oleh Badan Pengelola Keuangan dan Kekayaan Daerah melalui program intensifikasi dan ektensifikasi dan telah berjalan dengan baik hal ini ditunjukkan adanya peningkatan pajak daerah setiap tahunnya.

\section{Metode Penelitian}

Penelitian ini menggunakan pendekatan kualitatif dengan jenis penelitian studi kasus. Penentuan informan dilakukan secara Purposive Sampling yaitu dengan memilih informan dengan jumlah informan 8 yang dianggap representative orang untuk memberikan informasi mengenai "Strategi peningkatan pendapatan asli daerah melalui intensifikasi dan ekstensifikasi penerimaan pajak dan retribusi daerah di kabupaten Enrekang. Teknik pengumpulan data dilakukan dengan wawancara mendalam, observasi dan studi dokumen. Data kemudian dianalisis dengan reduksi data, penyajian data, dan penarikan kesimpulan

\section{Hasil Penelitian Dan Pembahasan}

Pada bab ini penulis mendeskripsikan hasil penelitian dan pembahasan terkait dengan strategi peningkatan pendapatan asli daerah melalui intensifikasi dan ekstensifikasi pajak daerah dan retribusi daerah di Kabupaten Enrekang. Adapun perbedaan penelitian sebelumnya yang pernah dilakukan dengan penelitian ini adalah Jenis penelitan sebelumnya adalah deskriptif kualitatif tetapi menggunakan kerangka fikir pariwisata dan penerimaan pajak dalam perspektif islam. Serta penelitian yang lain yang pernah dilakukan menggunakan deskriptif kualitataif dengan penelitian hukum sosiologis atau empiris yang mencakup penelitian terhadap identifikasi hukum tidak tertulis, serta proses interaksi sosiologis masyarakat dalam penerapan hukum. Sedangkan penelitian ini menggunakan sistem Intesifikasi dan sistem ekstensifikasi untuk mengukur strategi peningkatan Pendapatan Asli daerah di Kabupaten Enrekang

\section{A. Program Intensifikasi}

Intensifikasi adalah upaya yang dilakukan pemerintah untuk meningkatkan penerimaan daerah yang ditempuh melalui peningkatan kepatuhan subjek pajak yang telah ada. Upaya Intensifikasi dalam penelitian ini akan mencakup aspek kelembagaan, aspek ketatalaksanaan, dan aspek personalianya.

\section{Aspek Kelembagaan}

Menyesuaikan atau memperbaiki aspek kelembagaan/organisasi pengelolaan pendapatan asli daerah (PAD) merupakan salah satu upaya yang dilakukan dalam mengintensifkan Penerimaan daerah dan hal tersebut sudah sesuai dengan yang dilakukan dengan Bapenda Kab. Enrekang terlat dengan susunan struktur organisasi kelembagaan Bapenda Kab. Enrekang yang menerapkan sistem penempatan pegawai berdasarkan keahlian dalam menjalankan tugas pokok dan fungsinya pada masing-masng bidang di Bapenda Kab. Enrekang yang memberikan dampak positif terhadap 
peningkatan jumlah waib pajak dan jumlah penerimaan daerah di Kab. Enrekang.

\section{Aspek ketatalaksanaan}

a. Efisiensi dan Efektivitas Pungutan Pajak dan Retribusi daerah Upaya intensifikasi yang dilakukan dengan mengifisienkan dan mengefektifkan penerimaan melalui peningkatan jumlah wajib pajak dan wajib retribusi serta meningkatkan kegiatan penyuluhan kepada masyarakat untuk menumbuhkan kesadaran masyarakat membayar pajak dan retribusi daerah sudah sesuai dengan yang dilakukan Bapenda Kab.Enrekang hal tersebut dapat dilihat dengan adanya peningkatan jumlah wajib pajak dan penerimaan melalui pajak dan retribusi daerah, akan tetapi melalui peningkatan pemungutan pajak dan retribusi daerah dalam jumlah yang benar dan tepat waktunya, Peningkatan cara-cara penetapan pajak dan retribusi, serta peningkatan sistem pembukuan, sehingga memudahkan dalam hal pencarian data tunggakan pajak maupun retribusi yang pada akhirnya dapat mempermudah penagihannya masih belum sesuai dikarenakan penerimaan beberapaja jenis pajak masih belum dilakukan serta masih belum maksimal karena beberapa objek pajak masih belum dilakukan pungutan, belum ada inovasi yang mengarah pada peningkatan cara-cara pentapan pajak serta sistem pembukuan yang masih menggunakan sistem manual dikarenakan sistem yang sebelumnya yang lebih berbasis teknologi dinilai tidak memberikan kemudahan sehingga efiseinsi dan efektivitas pungutan pajak dan Retribusi daerah masih belum efektif

Tabel 1. Target dan Realisasi Pajak Daerah Kabupaten Enrekang Tahun 2013- 2018

\begin{tabular}{lllll}
\hline NO & Tahun & Target & Realisasi & Presentase \\
1 & 2013 & $\operatorname{Rp} 2.041 .000 .000$ & $\operatorname{Rp} 3.413 .931 .005$ & $167,27 \%$ \\
2 & 2014 & $\operatorname{Rp} 5.417 .500 .000$ & $\operatorname{Rp} 6.071 .708 .609$ & $112,08 \%$ \\
3 & 2015 & $\operatorname{Rp} 7.130 .000 .000$ & $\operatorname{Rp} 7.340 .370 .536$ & $102,95 \%$ \\
4 & 2016 & $\operatorname{Rp} 7.373 .000 .000$ & $\operatorname{Rp} 9.147 .4033 .707$ & $118,23 \%$ \\
5 & 2017 & $\operatorname{Rp} 9.965 .000 .000$ & $\operatorname{Rp} 9.022 .821 .580$ & $90,55 \%$ \\
6 & 2018 & $\operatorname{Rp} 10.783 .000 .000$ & $\operatorname{Rp} 10.202 .823 .433$ & $94,62 \%$ \\
\hline
\end{tabular}

Sumber :Badan pendapatan Daerah Kabupaten Enrekang tahun 2019

Tabel 2. Target dan realisasi Retribusi Daerah Kabupaten Enrekang tahun 20132018 


\begin{tabular}{lllll}
\hline NO & Tahun & Target & Realisasi & Presentase \\
1 & 2013 & $\operatorname{Rp} 11.502 .343 .500$ & $\operatorname{Rp} 9.329 .297 .320$ & $81,11 \%$ \\
2 & 2014 & $\operatorname{Rp} 21.957 .428 .963$ & $\operatorname{Rp~13.393.457.919~}$ & $61,00 \%$ \\
3 & 2015 & $\operatorname{Rp} 19.802 .406 .960$ & $\operatorname{Rp~15.557.657.681~}$ & $78,56 \%$ \\
4 & 2016 & $\operatorname{Rp} 22.609 .497 .500$ & $\operatorname{Rp} 19.879 .314 .053$ & $87,92 \%$ \\
5 & 2017 & $\operatorname{Rp} 30.165 .130 .944$ & $\operatorname{Rp} 21.472 .509 .412$ & $71,18 \%$ \\
6 & 2018 & $\operatorname{Rp} 33.757 .347 .000$ & $\operatorname{Rp} 32.236 .167 .687$ & $95,49 \%$ \\
\hline
\end{tabular}

Sumber : Badan Pendapatan Daerah (Bapenda) Kabupaten Enrekang 2019

Tabel 3. Target dan realisasi Pendapatan Asli Daerah Kabupaten Enrekang Tahun 2013-2018

\begin{tabular}{|c|c|c|c|c|}
\hline $\mathrm{NO}$ & Tahun & Target & Realisasi & Presentase \\
\hline 1 & 2013 & Rp 23.765.694.464 & Rp 25.954.477.944 & $109,21 \%$ \\
\hline 2 & 2014 & $\operatorname{Rp} 37.641 .158 .766$ & $\operatorname{Rp} 33.945 .145 .644$ & $90,18 \%$ \\
\hline 3 & 2015 & Rp 55.857.486.754 & Rp 50.355.757.354 & $90,15 \%$ \\
\hline 4 & 2016 & Rp 63.863.375.385 & $\operatorname{Rp} 54.633 .224 .642$ & $85,55 \%$ \\
\hline 5 & 2017 & Rp 136.152.091.582 & Rp 100.266.156.369 & $73,64 \%$ \\
\hline 6 & 2018 & Rp 129.615.126.867 & $\operatorname{Rp} 76.455 .644 .071$ & $58,99 \%$ \\
\hline
\end{tabular}

Upaya intensifikasi dengan cara memperbaiki atau menyesuaikan aspek ketatalaksanaan baik admininistrasi pungutan maupun operasional yang meliputi penyeseuain administrasi pungutan, penyesuaian tarif dan penyesuaian sistem tata laksana pungutan sudah sesuai dengn yang dilakukan oleh Bapenda Kab. Enrekang dapat dilihat dengan sistem yang menikuti aturan perda yang berlaku bagi pajak dan retribusi, sehingga dari penyesuaian administrasi pungutan, peyesuaian tarif, dan penyesuaian sistem tata laksana pungutan sudah sesuai dengan yang dilakukan oleh Bapenda Kab. Enrekang.

\section{c. Cara pengawasan pungutan}

Upaya intensifikasi melalui peningkatan pengawasan dan pengendalian yuridis masih belum maksimal dilakukan, sedangkan dalam aspek pengawasan dan pengendalian teknis serta pengawasan dan pengendalian penatausahaan sudah 
sesuai dengan yang dilakukan oleh Bapenda Kab. Enrekang dapat dilihat dengan sistem pengendalia da pengawasan yang dilakukan dengan bekerja sama dengan Organisasi perangkat daerah lain dan pengawasan langsung dengan cara turun kelapangan.

\section{d. Sanksi bagi Wajib pajak dan wajib Retribusi}

Upaya intensifikasi melalui aspek ketatalaksanaan yakni memberikan sanksi bagi wajib pajak dan wajib retribusi yang tidak taat dalam membayar pajak dan retribusi daerah masih belum maksimal dilakukan dapat dilihat dengan sistem surat teguran dan denda sebanyak $2 \%$ dari pokok pajak yang dilakukan tunggakan tidak efektif dalam menumbuhkan kesadaran masyarakat dalam membayar pajak.

\section{Aspek Personalia}

Peningkatan sumber daya manusia dalam pengelola pendapatan asli daerah dengan cara meningkatkan mutu sumber daya manusia atau aparatur pengelola pendapatan daerah dapat dilakukan dengan mengikutsertakan aparatnya dalam kursus keuangan daerah, juga program-program pendidikan dan pelatihan yang berkaitan dengan pengelolaan keuangan daerah sudah sejalan dengan yang dilakukan Bapenda Kab. Enrekang terlihat dengan Bapenda mengikutsertakan pegawainya dalam diklat fungsional dan manajerial serta diklat-diklat keuangan di tingkat pusat dan daerah.

\section{B. Program Ekstensifikasi}

1. Penciptaan sumber-sumber pajak dan retribusi daerah.

Upaya Ekstensifikasi dalam upaya meningkatkan penerimaan pajak daerah melalui penciptaan sumber-sumber pajak dan retribusi daerah sudah sesuai dengan yang dilakukan Bapenda Kab. Enrekang, hal ini dapat dilihat dengan penambahan jumlah objek pajak dari beberapa jenis pajak dan retribusi yang memberikan dampak positif kepada penerimaan daerah.

2. Kebijakan dibidang investasi.

Upaya ekstensifikasi yang dilakukan selain dari mencari sumber penerimaan baru adalah dengan melalukan kebijakan investasi dan kerja sama dengan perusahaan swasta maupun perusahaan daerah, hal ini sudah sesuai dengan yang dilakukan dengan Bapenda Kab. Enrekang dapat dilihat dengan kerja sama yang dilakukan Bapenda dengan Perusahaan swasta dan perusahaan daerah yang memberikan dampak postif terhadap penerimaan daerah dalam bentuk pajak dan retribusi

\section{Faktor Pendukung dan Penghambat Dalam Peningaktan PAD di Kabupaten Enrekang}

- Faktor pendukung : ada peningkatan kemajuan dari segi organisasi dari bidang menjadi badan adalah salah satu peningkatan untuk memperbaiki kinerja pengelolaan pendapatan asli daerah di Kabupaten Enrekang, Bapenda Kabupaten Enrekang dalam menjalankan tugas dimudahkan dengan jumlah pegawai honorer yang disesuaikan dengan keahlian untuk membantu kerja pegawai di berbagai bidang kerja di Bapenda. 
- Faktor Penghambat : masih ada beberapa kekurangan yang masih perlu ditingkatkan misalnya dari segi kantor Badan Pendapatan daerah yang belum representative, jumlah pegawai negeri sipil yang masih kurang serta tenaga ahli dalam pengoperasian sistem aplikasi dan teknologi dan SDM yang masih kurang yakni UPT yang masih lowong, juru pungut yang masih kurang serta koordinasi dengan OPD terkait pajak dan retribusi yang masih perlu diperbaiki.

\section{Kesimpulan}

Berdasarkan hasil pembahasan, maka dapat diperoleh kesimpulan sebagai berikut:

1. Upaya Intensifikasi melalui 3 aspek yaitu aspek kelembagaan, aspek ketatalaksanaan dan aspek personalia

- Aspek kelembagaan dalam Badan pendapatan Daerah sesuai dengan Undang-undang nomor 28 tahun 2009 tentang pajak daerah dan retribusi yang dilaksanakan oleh Badan pendapatan daerah Kabupaten Enrekang serta Peraturan Daerah nomor 11 tahun 2016 tentang pembentukan dan susunan organisasi, perangkat daerah Kabupaten Enrekang dan upaya intensifikasi melalui menyesuaikan dan memperbaiki aspek kelembagaan pengelolaan PAD sudah sejalan dengan yang dilakukan Bapenda Kab. Enrekang.

- Aspek ketatalaksanaan : a. Mengifisienkan dan mengefektifkan penerimaan melalui peningkatan jumlah wajib pajak dan wajib retribusi serta meningkatkan kegiatan penyuluhan kepada masyarakat untuk menumbuhkan kesadaran masyarakat membayar pajak dan retribusi daerah sudah sesuai dengan yang dilakukan Bapenda Kab.Enrekang, peningkatan pemungutan pajak dan retribusi daerah dalam jumlah yang benar dan tepat waktunya, Peningkatan cara-cara penetapan pajak dan retribusi, serta peningkatan sistem pembukuan, sehingga memudahkan dalam hal pencarian data tunggakan pajak maupun retribusi yang pada akhirnya dapat mempermudah penagihannya masih belum sesuai, b. Memperbaiki atau menyesuaikan aspek ketatalaksanaan baik admininistrasi pungutan maupun operasional sudah sesuai sejalan dengan yang dilakukan Bapenda Kabupaten Enrekang. c. Peningkatan pengawasan dan pengendalian yuridis masih belum maksimal dilakukan, sedangkan dalam aspek pengawasan dan pengendalian teknis serta pengawasan dan pengendalian penatausahaan sudah sesuai dengan yang dilakukan oleh Bapenda Kab. Enrekang. d. Aspek ketatalaksanaan yakni memberikan sanksi bagi wajib pajak dan wajib retribusi yang tidak taat dalam membayar pajak dan retribusi daerah masih belum maksimal dilakukan

- Upaya intensifikasi dari aspek personalia yag dilakukan Bapenda adalah dengan mengikutsertakan aparaturnya dalam pelatihan-pelatihan yang diadakan dilingkup Bapenda, pelatihan yang diadakan pemda terkait pengelolaan sistem aplikasi dan pelatihan pengelolaan keuangan serta pelatihan tingkat provinsi sampai pusat yang dilakukan dengan sistem bergiliran mengikutsertakan PNS dan beberapa non PNS, dan hal tersebut 
sudah sejalan dengan yang dilakukan Bapenda untuk meningkatkan Penerimaan melalui upaya intensifikasi.

2. Upaya ekstensifikasi melalui Penciptaan sumber-sumber pajak dan retribusi daerah dan kebijakan dibidang investasi.

- Upaya ekstensifikasi melalui Penciptaan sumber-sumber pajak dan retribusi daerah yaitu dengan mengadakan pendataan atau menginvertarisir berbagai objek yang berpotensi untuk dipungut pajak atau retribusinya hal tersebut terbukti dengan adanya penambahan jumlah objek, pajak BPHTB dan pajak Hiburan di beberapa Kecamatan dan penambahan jenis retribusi jasa usaha yakni retribusi pelayanan tera ulang pada tahun 2018, dan hal tersebut sudah sejalan dengan yang dilakukan Bapenda Kab. Enrekang dengan meningkatkan jumlah penerimaan daerah melalui penciptaan sumber-sumber pendapatan baru.

- Upaya ekstensifikasi melalui kebijakan dibidang upaya ekstensifikasi yang dilakukan adalah dengan bekerja sama dibidang investasi baik itu pemda dengan menyediakan sewa alat dan penyertaan modal di pemda, kerja sama dengan perusahaan lokal dalam hal pengelolaan galian C, pajak rokok dan reklame, hal tersebut sudah sejalan dengan yang dilakukan Bapenda Kab. Enrekang untuk meningkatkan PAD melalui kerja sama dibidang investasi

2. Faktor Pendukung dan Penghambat Peningakatan PAD di Kabupaten Enrekang :

- Kekuatan : ada peningkatan kemajuan dari segi organisasi dari bidang menjadi badan adalah salah satu peningkatan untuk memperbaiki kinerja pengelolaan pendapatan asli daerah di Kabupaten Enrekang, Bapenda Kabupaten Enrekang dalam menjalankan tugas dimudahkan dengan jumlah pegawai honorer yang disesuaikan dengan keahlian untuk membantu kerja pegawai di berbagai bidang kerja di Bapenda.

- Kelemahan : masih ada beberapa kekurangan yang masih perlu ditingkatkan misalnya dari segi kantor Badan Pendapatan daerah yang belum representative, jumlah pegawai negeri sipil yang masih kurang serta tenaga ahli dalam pengoperasian sistem aplikasi dan teknologi dan SDM yang masih kurang yakni UPT yang masih lowong, juru pungut yang masih kurang serta koordinasi dengan OPD terkait pajak dan retribusi yang masih perlu diperbaiki.

\section{Persantunan}

Ucapan terima kasih penulis ucapkan untuk kedua orang tua penulis, terima kasih untuk setiap perjuangan dan juga do'a dari orang tua penulis, Dalam penyusunan jurnal ini, penulis dengan segala kerendahan hati menyadari bahwa penyusunan Tesis ini dapat disusun dengan baik karena adanya dorongan dan bantuan dari berbagai pihak, oleh karena itu pada kesempatan ini penulis menyampaikan rasa 
terima kasih kepada : Bapak Prof. Dr. Muh. Nursadik, MPM selaku pembimbing I yang telah memberikan arahan dan masukan selama proses penyusunan jurnal ini. dan Bapak Dr. Muhammad Yunus, MA selaku Ketua Program Studi Administrasi Pembangunan sekaligus selaku pembimbing II yang telah memberikan arahan dan masukan dalam menyempurnakan jurnal ini, serta semua pihak yang telah membantu dalam penyelesaian jurnal ini, penulis mengucapkan banyak terima kasih.

\section{Daftar Pustaka}

Achsyariana, Andi Ulfa. (2017). Kontribusi Wisata Alam Gunung Nona Terhadap Pendapatan Asli Daerah (PAD) Kabupaten Enrekang. Skripsi, dipublikasikan Universitas Islam Negeri Alauddin Makassar.

Halim, Abdul. (2001). Akuntansi dan pengendalian keuangan daerah. UPP AMP YKPN. Yogyakarta

Halim, Abdul. (2001). Manajemen Keuangan daerah. UPP-AMP YPKN. Yogyakarta

Kustiawan, Memen. (2005). Upaya Intensifikasi dan Ekstensifikasi pendapatan asli daerah melalui peningkatan kualitas aparatur pemerintah daerah. Jurnal ilmu administrasi vol 2 no. 1

Rahmi, Ade. (2013). Pengaruh intensifikasi dan ekstensifikasi terhadap peningkatan pendapatan asli daerah guna mewujudkan kemandirian keuangan daerah. Universitas Negeri Padang

Rozali, Abdullah. (2000). Pelaksanaan otonomi luas dan isu federalisme sebagai suatu alternatif. Raja Grafindo Persada. Jakarta

Setyaningsi, Tri. (2009). Strategi Peningkatan Pendapatan Asli Daerah Dalam Rangka Pelaksanaan Otonomi Daerah (Studi Tentang Strategi Peningkatan Penerimaan Sektor Pajak di Kabupaten Sleman). Skripsi, dipublikasikan. Universitas Muhammadiyah Yogyakarta

Siahaan, Marihot P. (2005). Pajak Daerah dan Retribusi Daerah. PT Rajagrafindo Persada. Jakarta

Undang-Undang nomor 28 tahun 2009 tentang pajak dan retribusi daerah

Undang-undang No 33 Tahun 2004 Tentang Perimbangan Kekuasaan Antara Pusat Dan Pemerintahan Daerah

Peraturan Pemerintah Nomor 66 Tahun 2001 tentang retribusi daerah

Badan Pendapatan Daerah Kabupaten Enrekang Tahun 2019

Sumber : Tribunnews.com Diakses tanggal 25 Februari 2019 dari http : //makassar. tribunnews. com/2018/05/11/ bapenda -enrekang-gagal capai-target-padpada-triwulan-pertama-2018. 